\title{
2 \\ Irregular maritime migration as a global phenomenon
}

\author{
Marie McAuliffe and Victoria Mence ${ }^{1}$
}

The estimated number of international migrants has increased dramatically over the past 55 years, from estimates of around 77 million in 1960 to around 244 million in 2015 (United Nations Department of Economic and Social Affairs [UNDESA], 2016). During that time, the pace of movement has increased as more and more international travel links have emerged. There has been an expansion in migration pathways as access to air travel has increased, resulting in much greater diversity among international travellers (International Migration Institute [IMI], 2006, p. 2).

The volume of cross-border movements that many countries around the world are facing is increasing, and shows no signs of abating. In the US, it is estimated that up to 360 million cross-border movements occurred in 2013 (US Customs and Border Protection, 2014). In Australia, 14.5 million cross-border movements were recorded in program year 1996-97 compared to 31.6 million in 2011-12. The current estimate is that by 2020 Australia will experience 50 million movements per year across its border. Countries in Asia are also experiencing increases in movement, including labour migration to the economies of Singapore,

\footnotetext{
1 The authors are grateful for research assistance from Simone Gangell and Paul Hayes in the preparation of this chapter.
} 
Malaysia, South Korea and Thailand (Hugo, 2014). As access to international movement has increased, states have sought to implement a range of strategies to manage this increase in scale, pace and diversity. Immigration and border management policies and practices have rapidly evolved to meet changes in global circumstances and perceptions of risk associated with the movement of large numbers of people.

Alongside increased global mobility more generally, there has been, over recent years, an increase in refugees and asylum seekers globally. For example, United Nations High Commissioner for Refugees (UNHCR) data indicate that in 2000 there were around 19 million displaced persons ${ }^{2}$ worldwide, compared to 59.5 million in 2014 (UNHCR, 2015). ${ }^{3}$ There has also been a substantial increase in the number of displaced persons ${ }^{4}$ since the recent global low of 2003. The overall global population of displaced persons more than doubled between 2003 and 2014, from 14.8 to 59.5 million people.

Against this backdrop of increasing movement and human displacement, irregular migration poses enduring challenges, and irregular maritime migration most markedly. The humanitarian crisis in the summer of 2015 involving the maritime (and subsequently land) movements of hundreds of thousands of people from Syria, Afghanistan and elsewhere via North Africa and Turkey highlighted the considerable and highly visible policy challenges raised by irregular maritime migration.

While it is acknowledged that there are limitations in seeking to distinguish global irregular maritime migration from other forms of irregular migration as well as from broader asylum-related migration flows, it is also important to note that it is a phenomenon with attributes that are distinguishable from irregular migration by land and air. This paper attempts to articulate the key aspects of this phenomenon.

In preparing this chapter, one of the key issues it raised was the relatively minor focus irregular maritime migration has received in the academic literature compared to other related topics. Perhaps one of the reasons for

2 This figure comprises refugees, asylum seekers, internally displaced persons, stateless persons and various other populations of concern to UNHCR.

3 This figure includes 10.5 million refugees, 925,000 asylum seekers and 17.6 million internally displaced persons.

4 For the present purpose, 'displaced persons' comprise refugees, asylum seekers, internally displaced persons (IDPs), stateless persons and 'others' of concern. Other aggregate figures used by UNHCR may also include populations of returned refugees and returned IDPs. 
a more subdued level of academic enquiry is feasibility. While there can be no doubt that irregular maritime migration is a high profile, visually powerful form of irregular migration, the ability to conduct research on its various aspects is undoubtedly challenging. First, access to potential or actual irregular migrants who are willing to engage with researchers can be very difficult. The sensitive and profound nature of their experiences poses particular challenges. Second, the criminal aspects of irregular maritime migration have meant that aspects of counter people smuggling, transnational criminal networks and disruption are often unable to be examined fully due to the inability of accessing classified information, which is not readily available outside government (Koser, 2010). Third, the polarised nature of the public discourse surrounding irregular migration (and maritime migration in particular) makes examination of the topic in a balanced way difficult.

The somewhat more limited level of academic enquiry on the specific topic of global irregular maritime migration perhaps also needs to be viewed in relation to the seemingly, at times, frantic pace and significant focus it has been afforded in terms of policy deliberations of governments around the world, including those characterised as 'source', 'transit' and 'destination' countries. Attempts to study correlation and causality in complex and turbulent policy environments are likely to be compromised.

In terms of the structure of the chapter, the second section below discusses irregular migration, including definitions and data issues. The third section provides an overview of irregular maritime migration flows in key hotspots globally. The fourth section briefly outlines the multifaceted nature of irregular maritime migration. The fifth and final section concludes by highlighting some of the policy challenges in responding to irregular maritime migration.

\section{The broader irregular migration context}

Irregular maritime migration is commonly examined in academic literature as one element of the much broader occurrence of irregular migration, which in turn is a feature of modern migration patterns in an era of increased globalisation. The origins of irregular migration, and its links to forces driving the dramatic increase in international migration in the latter part of the twentieth century, are important themes in the 
literature. The increase in regular migration and the correspondingly rise of irregular migration has, in the view of many commentators, an irresistible momentum that is likely to continue (Koser, 2005, p. 7).

The increase in irregular migration is regarded by many commentators as an inevitable consequence of a globalised economy founded on integrated markets that fuel high labour demands and high levels of immigration (Castles, 2004; Hollifield, 2004). Hollifield looked at what he called the 'liberal' paradox whereby rich developed countries promote and embrace open channels of trade, money and labour (particularly by highly skilled migrants) whereas the mass movement of unskilled workers willing to work for low wages, also necessary to a globalised economy, face highly regulated migration controls. This tension between immigration restrictions and the demand for labour has, in Hollifield's view, driven the increase in irregular migration (Hollifield, 2004, p. 905).

For people facing very difficult (and possibly life-threatening) circumstances-including persecution, poverty, endemic corruption as well as lack of health care, education, employment and/or housing —and who have the ability to migrate, industrialised countries with good human rights records, sound economies and functioning civil societies will remain desirable destinations as they offer, in comparison to other countries, a higher standard of living and security as well as the ability to remit funds to people remaining in the country of origin. As noted by Terrazas (2011, p. 3), ' $[t]$ he notion that international migration is somehow related to the well-being of countries of origin is deeply intuitive'.

The substantial literature on the relationship between development and movement indicates that the ability to migrate is a significant issue. The ability to migrate is not related to the 'strength' of needs or the depth of direness faced, and some groups most in need do not have the resources or ability to migrate. Carling, for example, argued that those affected by extreme conditions such as warfare can have the strongest migration aspirations but a lack of ability to do so: a group he calls the 'involuntarily immobile' (Carling, 2002). Other significant research has found that as human development increases, and access to education, income, housing, transport and technology improves, the ability of people to migrate increases and populations become more mobile-the so-called 'hump migration' theory (Martin \& Taylor, 1996; Skeldon, 1997; Zelinsky, 1971). De Haas has argued that the relationship between development, economic growth and migration is fundamentally nonlinear so that, for 
example, while 'a lack of freedoms is likely to fuel migration aspirations, the same lack of freedoms may simultaneously decrease people's capabilities to migrate' (de Haas, 2011, p. 14).

\section{The securitisation of migration}

In the academic literature, international migration has been characterised as a non-traditional security issue in the post-Cold War period, along with other phenomena such as food and energy access, international terrorism, drug trafficking and transnational crime. A school of academic thought - the Copenhagen School—conceptualised 'securitisation' as the characterisation of danger and threat of a particular kind via a speech act that moved 'security' from the military realm to other realms, such as migration (Weaver, 1995).

The end of the Cold War, and the related demise of a powerful external threat to the security of the West, enabled the emergence of threats, or perceived threats, that involved non-state actors. This had implications for a range of global and international issues, particularly those that were not (adequately) regulated between states, or those that operated outside of states' control, such as international terrorism. Migrant smuggling and human trafficking are other examples of threats involving non-state actors that would appear to be largely beyond regulation.

Faist argued that one of the effects of the events of 11 September, 2001 was that it reinforced the trend towards securitising migration, which directly resulted in increased migration control, significant investment in border management systems and substantial institutional responses (such as the formation of the US Department of Homeland Security, which incorporated the former Immigration and Nationalisation Service), most notably in the US but more generally throughout the Western world (Faist, 2004). In Miggiano's view, the intensification of border controls is an overt demonstration of the securitisation of migration processes that is especially apparent with the deployment of military resources to manage sea borders (Miggiano, 2009, pp. 1-8).

Relatedly, public administration of migration has changed over time, with greater focus being afforded to security aspects, as reflected in the changed roles and responsibilities of government departments and agencies. 
Migration has increasingly become a focus of security-related agencies, although the implications resulting from the changing focus for migration as a public policy issue remain unclear (Koser, 2012).

Some of the other consequences of securitising migration discussed in the literature include aspects related to migrant integration (Ceyhan \& Tsoukala, 2002; Huysmans, 2000; Mulvey, 2010) as well as the heightened expectations of the public that governments should, and are able to, control transnational movements across their borders (Faist, 2004, p. 4). Issues of human security are also addressed, as well as the tensions between national security concerns and human security, which 'broadens the scope of security analysis and policy from territorial security to the security of people' (Gomez \& Gasper, 2013), especially in relation to migration policies and the negative impacts on migrants (Doneys, 2011).

The implications for the management of irregular migration are potentially profound. There is no doubt that the phenomenon is currently portrayed as a security issue in destination countries, and some argue that the impact of the securitisation of migration in the twenty-first century is on course to intensify (Humphrey, 2013).

\section{The role of telecommunications and the media}

The role of telecommunications and the media's portrayals of migration should not be underestimated, particularly in the context of increasing migration flows and the technological advances in communications contributing to globalisation (Hopkins, 2009). Coverage of migration in various media, such as newspapers and television, has been noted for its polarisation, particularly in Europe. Key findings by academics indicate that references to migration in the media are generally episodic rather than consistent, increasingly focused on irregular migration, and are often associated with topics of criminality or border protection (Kim, Carvalho, Davis, \& Mullins, 2011; Pickering, 2001; Threadgold, 2009). The securitisation of migration in recent times is prevalent in media coverage on migration (Global Commission on International Migration [GCIM], 2005; Koser, 2012).

A more recent issue concerning irregular migration and media coverage is the possibility that public information could be exploited by people smugglers. With the launch of Operation Sovereign Borders in September 
2013, the Australian Government restricted the dissemination of information on operational matters, citing public interest immunity. The decision to not release operational information was based on the grounds that such information would place people involved in operations at risk and unnecessarily cause damage to Australia's national security, defence and international relations (Morrison, 2014). Part of the rationale was also that such information would provide migrant smugglers with the opportunity to avoid detection or to precipitate a search and rescue response (Campbell, 2014).

Improved telecommunications provide migrants greater access to information, and act to strengthen social bonds between diaspora and countries of origin. Access to remittances via enhanced technology is also likely to be relevant to particular groups. As highlighted by Vertovec (as cited in Nedelcu, 2012, p. 1341):

[Information communications technologies] enable new forms of migrant transnationalism characterised not only by the growing intensity of transnational exchanges and activities, but also by a ubiquitous system of communication that allows migrants to connect with multiple, geographically distant and culturally distinct worlds to which they identify and participate on a daily basis.

Family, friends and community members who have migrated internationally inspire potential migrants to achieve the same outcome and can provide tangible assistance to migrate, including information, funds and advice. Together with enhanced 'real time' communications technology, these networks provide potential migrants with an improved ability to assess their migration options. It is important, however, not to overestimate the impact of newer communications technologies. Despite the internet being considered a global communications medium, for example, access to the internet is still limited in many locations. This makes accurate measurement of its level of influence difficult (Rabogoshvili, 2012). Further, access alone does not ensure adoption of new technologies. Differential access by race, class, sex and ethnicity are factors in technological engagement (Panagakos \& Horst, 2006). Access to mobile telephones, however, appears to have increased dramatically, as can be seen in Figure 2.1. 


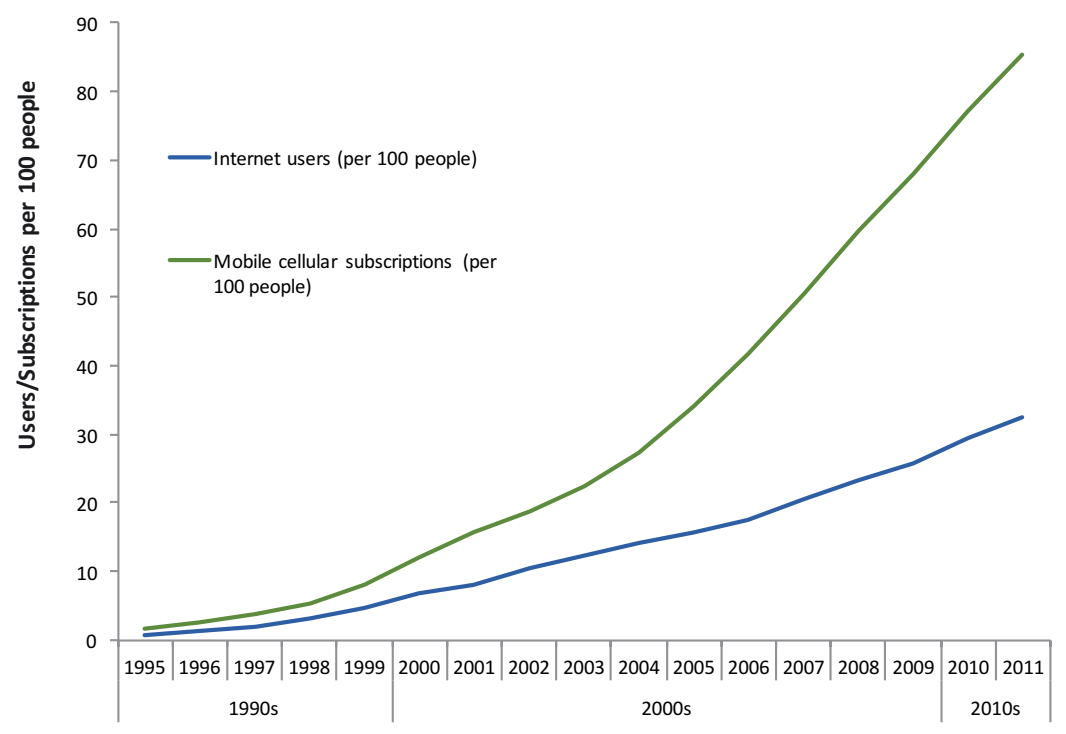

Figure 2.1: Global internet and mobile telephone access

Source: Data extracted from World Bank (2015). A similar version of this graph was published by The Brookings Institution on 25 February, 2014, www.brookings.edu/ research/interactives/2014/snapshot-6-rorschach-tests-international-order.

\section{Interconnectedness, diaspora and mobility}

The influence of diaspora has long been considered a factor in migration, including irregular migration. Diaspora provide social networks for potential irregular migrants, which can serve as 'feedback mechanisms' (Banerjee, 1983; Crisp, 1999; Meyer, 2001). These networks consist mostly of family, friends, community or religious organisations, as well as people smugglers and others who assist in the migration journey (Koser $\&$ Pinkerton, 2002). Once established, social networks may facilitate further migration, including affecting destination choice, providing information and material assistance, and offering a source of emotional support.

While empirical evidence about the role of social networks in irregular migration is more limited (Crisp, 1999; de Haas, 2011; Staring, 2004), it is probable that transnational networks play a vital role in helping people circumnavigate the challenges involved in irregular migration (Crisp, 1999). It has been noted that such networks are especially important in providing the organisational infrastructure required for people to migrate clandestinely or irregularly, i.e. through people smuggling, the trafficking of persons or the irregular movement of asylum seekers. 
In addition to facilitating the migration process itself, transnational social networks provide irregular migrants with subsistence and support upon arrival (Crisp, 1999). Important for any migrant, the provision of support in the form of possible sources of income and assistance is particularly vital for illegal migrants (Blaschke, 1998), who are more restricted from accessing employment opportunities or possibly even their own financial holdings in their country of origin.

Interconnections between diaspora and communities in their country of origin are perhaps stronger than ever before as a result of increased access and technological improvements in telecommunications and travel. The use of the internet in particular has been viewed to have strengthened transnational networks, putting those who have migrated in contact not only with their immediate family and friends, but with 'virtual ethnic communities' on the basis of common descent (Conversi, 2012).

For all that is known about the influence of diaspora on migration, there is much that is assumed, particularly relating to irregular migration. The difficulties with conducting research on irregular migration discussed in the introduction of this paper have resulted in a knowledge gap regarding irregular migrants' decision-making processes that, if filled, would reveal more about the role of diaspora in irregular migration.

\section{Data and definitions}

According to the latest UNDESA Population Division report on international migration, in 2015 an estimated 244 million people, or 3.3 per cent of the world's population, were international migrants, compared with 175 million in 2000 and 154 million in 1990. Between 1990 and 2013, the estimated number of international migrants worldwide rose by over 77 million or by 50 per cent. Much of this growth occurred between 2000 and 2010 (UNDESA, 2016).

In terms of the proportion of migrants that are thought to travel irregularly, broad estimates are available to provide indications of irregular migration globally. The United Nations, for example, has estimated that globally there are approximately 30 to 40 million irregular or undocumented migrants, a number that equates to between 15 and 20 per cent of all international migrants (UNDESA, 2003). 
Some commentators question the utility of attempting to quantify irregular migration, citing the practical difficulties as well as the underlying rationale for collecting and citing such statistics, which can amount to alarmism (Castles, 2002; Clarke, 2000). There are, however, clear benefits in attempting to quantify irregular movements, including from the perspectives of national governments, regional and local governments, international organisations, service providers, employers and others. A better understanding of irregular migration, including in relation to quantity, allows for the development of responses and mitigation strategies as a means of managing the multitude of potentially conflicting interests.

\section{Challenges in defining and quantifying irregular migration}

Understanding the scale and nature of irregular migration is important, not only in national and regional contexts but also in a global context, as a means of identifying trends and patterns for a range of policy, economic and geopolitical reasons. There are, however, significant challenges in establishing reliable estimates upon which meaningful analysis and useful comparisons can be made (Koser, 2010). A summary of these challenges is included in Table 2.1, which highlights the inherent difficulties in accurately placing the quantum of irregular migration in a broader context.

Table 2.1: Difficulties in measuring irregular migration

\begin{tabular}{|l|l|}
\hline Aggregating data & $\begin{array}{l}\text { Tends to disguise the complexity of irregular migration, e.g. 'mixed } \\
\text { flows' consists of economic migrants and those fleeing persecution } \\
\text { Lack of comparable data both over time and between locations }\end{array}$ \\
\hline Media & $\begin{array}{l}\text { Media tendency to focus on the highest available estimate } \\
\text { Statistics may be used more to alarm than inform }\end{array}$ \\
\hline $\begin{array}{l}\text { Confusion in } \\
\text { definitions }\end{array}$ & $\begin{array}{l}\text { Irregular migration covers a range of people who can be in an } \\
\text { irregular situation for different reasons, and people can switch from } \\
\text { a regular to irregular status, or vice versa }\end{array}$ \\
\hline Stocks and flows & $\begin{array}{l}\text { Can be difficult to differentiate between the two and discern what } \\
\text { is actually being counted } \\
\text { Flows usually only focus on entries, not exits or return flows } \\
\text { Stocks assume permanence, when migrants may leave, change } \\
\text { their status or die } \\
\text { Impossible to combine both stocks and flows to gain a total estimate }\end{array}$ \\
\hline Data accessibility & $\begin{array}{l}\text { Often collected by enforcement agencies and not made } \\
\text { publicly available }\end{array}$ \\
\hline $\begin{array}{l}\text { Sensitivities } \\
\text { around human } \\
\text { rights }\end{array}$ & $\begin{array}{l}\text { There may be some nondisclosure of irregular migrants by various } \\
\text { parties (e.g. employers) making quantifying the number of irregular } \\
\text { migrants difficult }\end{array}$ \\
\hline
\end{tabular}

Source: Koser (2010). 
Part of the difficulty is related to definitional issues, which may differ by jurisdiction, as well as the wide-ranging nature of 'irregular' status, which can result, for example, from people entering countries undetected through sophisticated smuggling operations as well as from minor administrative issues that have the effect of rendering a person irregular. A useful summary of the main categories of irregular migrants is summarised in Table 2.2, highlighting the complexity of 'irregularity', which clearly has its more benign forms, particularly when viewed in the border management and/ or security context.

\section{Table 2.2: Definition of irregular migration}

\begin{tabular}{|l|l|}
\hline \multicolumn{2}{|l|}{ In principle, irregular migration populations can be divided into five categories: } \\
\hline 1 & $\begin{array}{l}\text { Migrants who have illegally entered the country by either physically evading formal } \\
\text { immigration control or presenting false papers. }\end{array}$ \\
\hline 2 & $\begin{array}{l}\text { Migrants who legally entered the country for a fixed period which has expired; they } \\
\text { did not renew their permission to stay and are therefore unlawful overstayers. }\end{array}$ \\
\hline 3 & $\begin{array}{l}\text { Migrants who are lawfully entitled to reside in the country, but are in breach of some } \\
\text { visa condition, notably by working more than their immigration status permits. }\end{array}$ \\
\hline 4 & $\begin{array}{l}\text { Asylum seekers who legally entered the country to pursue a case for refugee } \\
\text { status, but who remain despite a final decision refusing them a continuing right } \\
\text { to remain. }\end{array}$ \\
\hline 5 & $\begin{array}{l}\text { Children born in the country to such 'irregular migrants', who also lack a right } \\
\text { to remain although they are not themselves migrants. }\end{array}$ \\
\hline
\end{tabular}

Source: Gordon, Scanlon, Travers, and Whitehead (2009).

Difficulties in quantifying irregular migration notwithstanding, it can be an important exercise, not least because it highlights the very substantial differences in estimates. In this regard, the imprecise nature of the task of quantification becomes apparent, and the need to treat data on irregular migration with caution is underscored. For example, estimates on the number of irregular migrants in Europe has varied widely from two to eight million (Koser, 2005). Recent reports estimate that there are around 12 million in the US (Hoefer, Rytina, \& Baker, 2011). Some reports estimate that there are 'several' million irregular migrants in South and South East Asia, and between three and five million in South Africa (Koser, 2005). Further information on the estimated number of irregular migrants in selected locations is in Table 2.3. 
Table 2.3: Estimated size of irregular migrant populations by region/ country

\begin{tabular}{|l|c|r|c|}
\hline \multirow{2}{*}{ Region/country } & Time period & $\begin{array}{r}\text { Estimated population } \\
\text { (stock) }\end{array}$ & Source \\
\hline \multirow{3}{*}{ European Union } & 2007 & 4.5 million & (a) \\
\cline { 2 - 4 } & 2008 & $1.9-3.8$ million & (b) \\
\hline \multirow{3}{*}{ United Kingdom } & 2008 & 8 million & (c) \\
\cline { 2 - 4 } & 2007 & $417,000-863,000$ & (d) \\
\hline \multirow{3}{*}{ Italy } & 2009 & 750,000 & (e) \\
\cline { 2 - 5 } & 2008 & 651,000 & (f) \\
\cline { 2 - 5 } & 2010 & 544,000 & (g) \\
\hline Greece & 2011 & $<500,000$ & (g) \\
\hline Spain & 2011 & $172,000-390,000$ & (f) \\
\hline United States & 2009 & $300,000-390,000$ & (f) \\
\cline { 2 - 5 } & 2007 & 12.2 million & (g) \\
\cline { 2 - 5 } & 2010 & 11.7 million & (g) \\
\hline South Africa & 2012 & $3-5$ million & (i) \\
\hline Saudi Arabia & 2005 & 1 million+ & (j) \\
\hline Yemen & 2013 & $25,000+$ & (k) \\
\hline Australia & 2013 & 53,900 & (l) \\
\cline { 2 - 5 } & 2010 & 58,400 & (m) \\
\hline
\end{tabular}

Source: (a) Council of Europe (2007), p. 8. (b) Clandestino Project (2009b), p. 4. (c) Frontex (2010), p. 9. (d) Gordon et al. (2009), p. 7. (e) Koser (2010), p. 186. (f) Clandestino Project (2009a), p. 1. (g) European Migration Network, (2012), p. 213. (g) Passel, Cohn, \& GonzalezBarrera (2013). (h) Rosenblum (2012). (i) Koser (2005). (j) Walker (2013). (k) Regional Mixed Migration Secretariat (2013). (I) Department of Immigration and Border Protection (DIBP) (2010). (m) Australian National Audit Office (ANAO) (2013), p. 39.

In a global context, irregular migration to Australia constitutes a very small proportion of all irregular migration, especially when compared to the US and Europe. More than five million temporary entrants visited Australia in 2012-13, with 16,460 persons recorded who did not leave when their visas expired. In the same period, some 25,100 people arrived irregularly by boat. 


\section{Irregular maritime migration flows}

Unlike other forms of irregular migration, the numbers of irregular maritime migrants moving from poor, less developed and/or conflict ridden countries in Asia, Africa, Latin America and the Middle East to developed countries, such as the flows heading for the US, Europe and Australia, are relatively well documented. One of the reasons that this movement is monitored so closely is that it is highly visible. It also tends to be a focus of intense public interest. As a consequence, there has been in more recent times the development of highly regulated border management processes that have increased the capacity to count and report on the scope of irregular maritime flows.

The US Coast Guard, for example, reports precise figures going back to 1995 . The EU's Frontex has increased its capacity, especially since 2008, to report on the number of persons detected while undertaking maritime migration in the Mediterranean and North Atlantic. In the Indian Ocean, the number of irregular migrants heading to Australia is recorded in some detail, although public reporting has tended to be at the aggregate level. These flows are typical of the focus on 'South-North' movement, and highlight the interest in monitoring irregular maritime migration the North.

The appetite for monitoring and reporting on such flows would appear to be considerable. There is also an issue of capability. Highly industrialised, richer destination countries, as opposed to poorer, less developed destination countries, have greater capacity to monitor and report on irregular maritime migration. Perhaps the largest, most significant flows of irregular maritime migrants occur well outside the three 'South-North' hotspots of the US, Europe and Australia, as the examples of IndonesiaMalaysia maritime migration and Africa-Middle East maritime migration discussed below appear to indicate, notwithstanding the lack of reliable statistics.

The scale of irregular maritime migration is difficult to quantify outside of the main South-North migration corridors. That said, even as recently as 10 years ago, such movement into Europe was not monitored and reported on in the highly systematised way it is today through Frontex. Overall, irregular maritime migration is able to be quantified in specific locations, namely the Caribbean Sea to the US, the Mediterranean Sea to Europe and the Indian Ocean to Australia. In recent years, Canada has 
experienced incidents of large noncommercial vessels of several hundred passengers arranged by smugglers, although this has been limited (e.g. the MVs [motor vessels] Sun Sea and Ocean Lady in 2009).

Data tends to capture interdictions/detections, and so clearly does not capture all attempts (successful or otherwise). It is likely that there are successful undetected maritime ventures in all contexts, but arguably this is less likely in some circumstances. For example, it is possible that failing to be intercepted off the northwest coast of Australia by authorities may result in irregular migrants perishing in the very harsh and isolated coastal regions; the need to be detected by authorities is a genuine one.

\section{South-North irregular maritime migration: US, Europe and Australia}

The Caribbean is the major region for undocumented maritime migrants attempting to enter the US, predominantly from Haiti, Cuba and the Dominican Republic. Since 1982, almost 50 per cent of migrants interdicted at sea were Haitians $(118,700)$, followed by Cubans (29 per cent or 70,700 migrants) and migrants from the Dominican Republic (15 per cent or 36,600 migrants). Trend data, as shown in Figure 2.2, illustrates the very substantial increases in the early to mid-1990s, and the subsequent tapering off of interdictions.

Information gathering on irregular migration into the EU, either by land, air or sea, has been coordinated by Frontex since it began operations in 2005. Prior to this, each member state was responsible for its own marine surveillance along the EU's southern borders. As a result, historical statistics on the number of detections of illegal entry by sea are difficult to aggregate. Frontex data indicate that there were peaks and troughs in maritime migration since 2009, until the dramatic increase in 2015. Between 2009 and 2014, the number of maritime irregular detections had been low (mainly under 40,000 per quarter). Then, in 2015, more than 850,000 travelled through the Eastern Mediterranean route from Turkey to Greece (Frontex, 2015). 


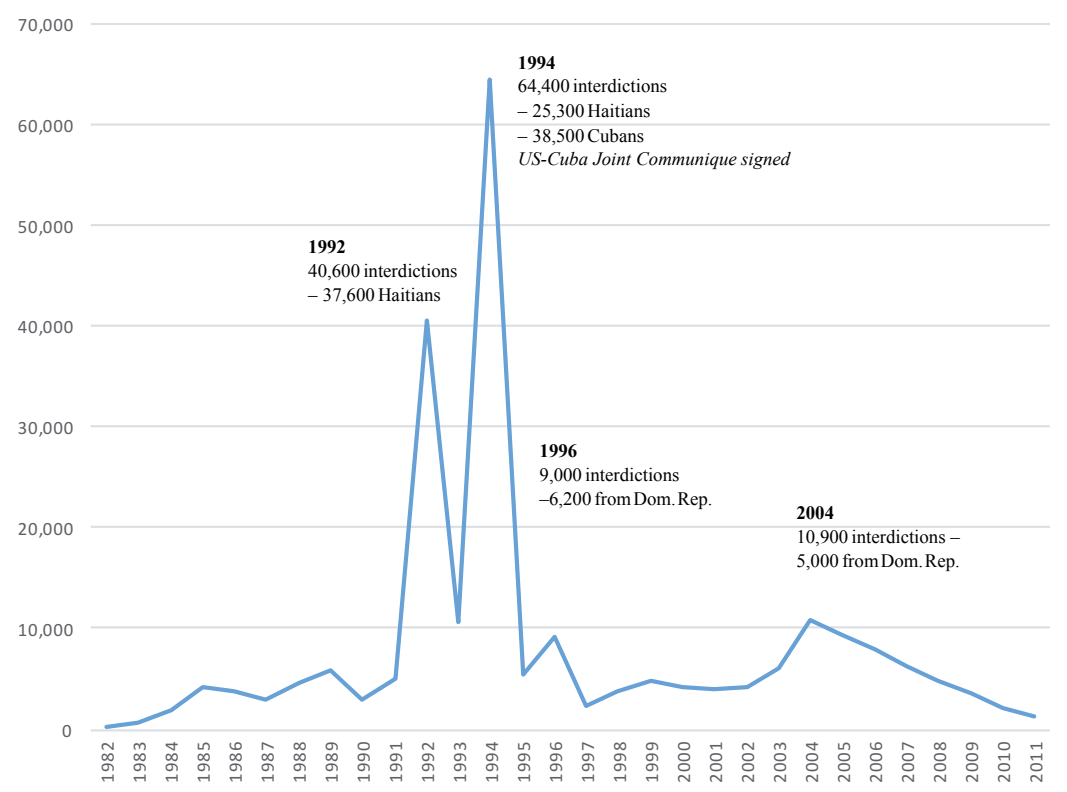

Figure 2.2: Maritime migrant interdictions since 1982 by fiscal year Source: Adapted from United States Coast Guard (2014).

Since the mid-1970s, Australia has received over 69,000 irregular maritime arrivals (IMAs). The vast majority of these (71 per cent, almost 49,000) arrived in the last four calendar years. The year 2013 experienced the largest volume of IMAs to Australia ever recorded, with over 20,700 arrivals. A total of 41 citizenship groups have arrived in Australia since 2008. Figure 2.3 shows the trend of IMAs to Australia since the 1970s. The significant decline at the end of 2013 reflects the measures taken by the Australian Government that resulted in only 157 IMAs arriving in 2014.

Analysis of official data published by Australia, the US and the EU suggests a differentiation in the way irregular migrants enter key destination countries, predominantly reflecting geography. Figure 2.4 shows that the vast majority of irregular migrants detected in 2012 were attempting to enter Australia by sea (92 per cent). By comparison, the majority of detected irregular migrants to the US were by land. In the EU, land travel comprised a higher proportion of irregular migration than sea travel, noting that air detection statistics were not available. Ideally, trend analysis would be able to provide a fuller picture of the relativities within regions, and more accurately highlight differences between regions, particularly given the fluctuations in Europe between land and sea detections. 


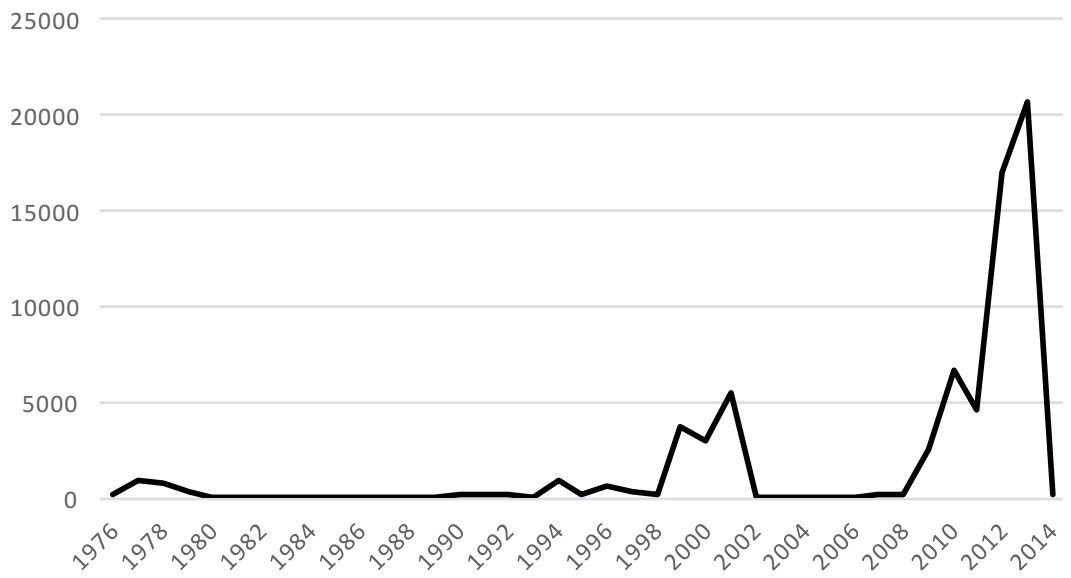

Figure 2.3: Number of IMAs to Australia, 1976-2014

Source: Adapted from Phillips \& Spinks (2013); updated using unpublished departmental data.

Based on most accounts, the scale of detected and undetected irregular migration (South to North) and number of unauthorised persons at any given time in the US and Europe is substantial and indicates that irregular maritime migration at the borders constitutes a small part of irregular migration. In contrast, the situation in Australia is different - as an island continent, geography, sea borders and relative isolation provide Australia with a unique ability among industrialised countries to manage its border. Australia does not have the vast and porous land borders that characterise the border management problems faced by the US and Europe, and maritime migration is the main manifestation of irregular migration in the Australian context.

Placing irregular maritime movements in the context of irregular migration more broadly is an important step in assessing the significance of irregular maritime migration, particularly in relation to calibrating policy responses. While this is not a straightforward exercise, and should be treated with some caution, Figure 2.4 does highlight the different dynamics occurring in different national and regional settings. This perhaps may go some way to explain the levels of focus afforded to the different forms of irregular migration. 


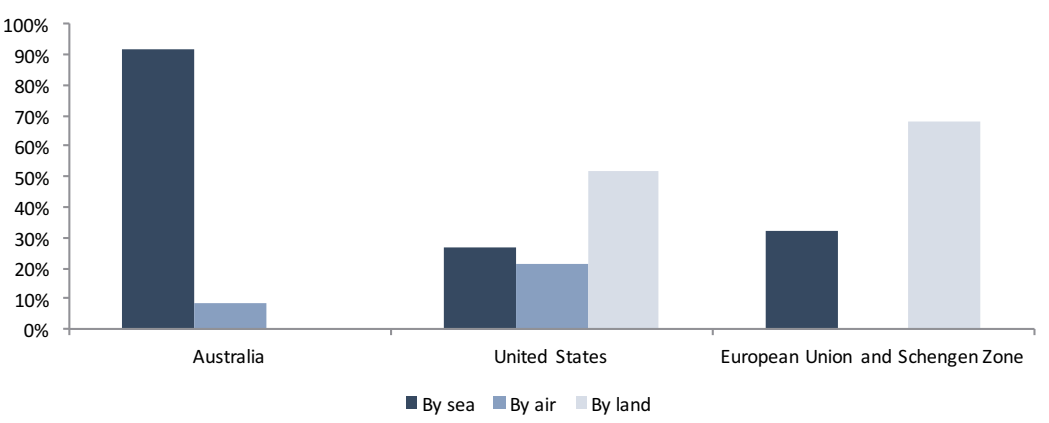

Figure 2.4: Proportion of detected irregular arrivals by region and mode of travel around 2012

Source: Data for Australia was sourced from the Department of Immigration and Citizenship (DIAC) (2012-13). Data for the US was sourced Simanski and Sapp (2012). Data for the EU was sourced from Frontex (2013).

Note: Sea arrivals for Australia were based on 25,000 irregular maritime arrivals (excluding vessel crew members) and excluded a small number of illegal foreign fishers and people who arrived on a scheduled cargo or cruise vessel and were refused entry at a seaport. Air arrivals were based on those who arrived on a scheduled flight and were subsequently refused entry at an airport. Data for the US relates to approximately 193,000 aliens determined inadmissible at a US border. It excluded some 360,000 persons apprehended at border control points, as a breakdown of these persons by mode of travel was unavailable. Data for the EU relates to over 72,000 illegal border crossings between border control points for 27 countries in the EU and 3 Schengen associated countries (Norway, Iceland and Switzerland). Data for unauthorised air arrivals for the entire EU was unavailable. The proportions are for illustrative purposes only, and are based on the number of detected irregular arrivals by mode of travel. The data does not include estimates for undetected border crossings, and does not take into account variations in proportions over time. Note that the graph refers to proportions, not absolute volumes. The reference period for Australia is Australian Financial Year 2012-13; ${ }^{5}$ the US is Fiscal Year 2012; ${ }^{6}$ the EU is calendar year 2012.

\section{Further examples of irregular maritime migration: Horn of Africa and South East Asia}

Another region of substantial irregular maritime activity, involving migrants mainly from Ethiopia and Somalia, is the Gulf of Aden and the Red Sea between the Horn of Africa to Yemen. The organisation responsible for recording this movement is the Regional Mixed Migration Secretariat. The capture of data has improved steadily since 2010 . While the reporting may not capture every movement the numbers reported give

5 Australian Financial Year 2012-13 is 1 July 2012 to 30 June 2013.

6 United States Fiscal Year 2012 is 1 October 2011 to 30 September 2012. 
a clear indication that the scope of irregular maritime movement involved is substantial. Around 500,000 people are estimated to have crossed the Gulf of Aden between 2007 and 2013.

Other flows tend to be more clandestine. Based on the migration characteristics of various citizenship groups and their inability to access regular travel pathways, there are thought to be significant numbers of people moving by boat in the South East Asian region. Many of these people appear to be undocumented migrant workers seeking work in neighbouring countries. Others travel to Indonesia from where they join boats to Australia. The true scale of this movement is thought to be substantial and used mainly by those who lack the capacity to travel via regular pathways, although the numbers are difficult to track and there is limited data to report. There are estimated, however, to be around two million irregular migrants in Malaysia alone (International Organization for Migration [IOM], 2010).

Media reporting on sudden flashpoints or hot spots is triggered, more often than not, by tragic incidents such as boats sinking, loss of life at sea or a sudden and unexpected upsurge in movement. Extensive media reports, for example, indicate that since the dramatic increase in interethnic violence in Rakhine province in Myanmar from mid-2012, there has been a substantial increase in the maritime migration of Rohingya from Myanmar and neighbouring Bangladesh to Thailand, Malaysia, Indonesia and beyond. This flow became a humanitarian crisis in May 2015 when thousands of Rohingya and Bengali migrants were stranded at sea, having been pushed back by Thai, Indonesian and Malaysian authorities.

\section{The multifaceted nature of irregular maritime migration}

In seeking to understand the complexity of irregular maritime migration as a dynamic global phenomenon occurring within broader global forces, it is important to critically examine some of its key aspects. While it is beyond the scope of this chapter to examine the multitude of issues that may relate to the phenomenon, an attempt to draw out the key aspects has been made. These are discussed in this section and include: geography and mode of transport; non-state actors and migrant smuggling; international obligations and state sovereignty; and migrants' motivations. 


\section{Geography and mode of transport}

Geography plays a fundamental role in irregular migration flows. The physical proximity of source and destination countries as well as the nature of their geographic positioning-land borders, sea/ ocean channels-is a significant factor in people movement. The ease (or otherwise) by which people are able to travel irregularly using different modes of transport is an important factor. For example, around 266,000 Mexicans are estimated to have been apprehended trying to enter the US overland in 2012 (Passel, Cohn, \& Gonzalez-Barrera, 2013), whereas 79 Mexicans were intercepted by US Coastguards in 2012 (United States Coast Guard, 2014).

While not wishing to overgeneralise, and noting that all forms of irregular movement would involve considerable challenges and difficulties for migrants, the ability to undertake land border crossings (however perilous) is likely to involve a reduced level of organisation and logistical support compared to maritime migration. First, maritime migration usually involves groups of people rather than individuals and so requires at least a basic level of organisation. Second, infrastructure in the form of a seaworthy vessel is required to make the journey, involving logistics and cost. Land border crossings, on the other hand, can be undertaken by individuals and do not require the same level of infrastructure and organisational support.

This has implications for direct movements between source and destination countries - the huge volume across the US-Mexican land border being a case in point - as well as for the relative ease in which transit countries can be entered. Transit countries with long porous land borders (e.g. Libya, Egypt, Morocco) may perhaps pose fewer constraints than transit countries with different geography (e.g. Indonesia, Malaysia). Many irregular maritime migrants to Spain, for example, travel from different locations in sub-Saharan Africa through land borders of Morocco before travelling by sea to Spain or entering via the Spanish enclaves Ceuta and Melilla (de Haas, 2005). Movement to Australia, on the other hand, presents a unique dynamic in that not only is Australia without a land border, but as well its main transit country (Indonesia) has limited land borders given its island composition.

The fundamental role of physical geography, while able to be overcome via air travel, is arguably a more important aspect now compared to 15 to 20 years ago, and prior to the significant increase in screening of air travellers 
(Faist, 2004). It is likely with the recent advances in border control and identity verification technology, air travel offers fewer opportunities for irregular migrants seeking to enter destination countries, although people using genuine travel documentation based on a fraudulent identity remain a considerable challenge, one that is being increasingly addressed through the use of biometric technology.

It is possible that, overall, the tightening of air travel has had an impact on irregular migration via other modes (land and sea). There is no doubt that irregular migration by land border crossing and maritime venture continue to be viewed as viable options by migrants, agents and smugglers where these options are available, and particularly given that citizens of many countries who travel irregularly are unable to access regular migration pathways (see Table 2.1). In addition, and as discussed above, a certain level of organisational capability needs to be in place to support irregular maritime migration, and while this may act as a constraint, it may also enable/encourage the expansion of unregulated actors (e.g. organisers, smugglers and corrupt officials).

\section{Non-state actors and migrant smuggling}

There has been substantial research and enquiry into migrant smuggling processes and dynamics, predominantly in relation to migrant smuggling into Europe, and in the context of the Protocol against the Smuggling of Migrants by Land, Sea and Air. In a 2011 report by the United Nations Office on Drugs and Crime (UNODC), a global review of migrant smuggling revealed a number of dynamics and characteristics that highlight the considerable challenges in tackling and reducing smuggling - see the summary of the UNODC report below. More recently, the UNODC has highlighted the significant role corruption plays in migrant smuggling, noting that (UNODC, 2011, p. 3):

Migrant smuggling could not occur on the large scale that it so often does
without collusion between corrupt officials and criminals. Corruption
seriously undermines national and international efforts to prevent and
control the smuggling of migrants ... [it] may occur in countries of origin,
transit, or destination. It may be systemic, institutional or individual.

The organisational capabilities of non-state actors involved in irregular migration, including corrupt officials, agents, organisers and smugglers, has undoubtedly been assisted by changes in telecommunications, which offer greater opportunities for people to participate successfully in the 
movement of people irregularly. In this sense, smuggling networks are able to occur largely outside of effective state regulation, allowing perhaps a greater degree of 'opportunism' by a wider range of actors than has occurred in the past. The notion of organised, 'apex' smuggling systems that are controlled by mafia-type bosses has largely given way to recognition that smuggling involves less organised, highly agile networks of relationships (Pastore, Monzini, \& Sciortino, 2006, p. 109):

the evolutions of the smuggling industry does $[s i c]$ not seem to produce highly structured and hierarchically governed organisations, but rather flexible coalitions managed through contractual agreements and repeated interactions.

Targeting of operational and policy responses to reduce the viability of migrant smuggling for the range of actors involved has been a key focus of governments, including in relation to irregular maritime migration (Koser, 2011). Such responses will undoubtedly continue to be central components in strategic and tactical efforts to reduce irregular maritime migration.

Other commentators have drawn attention to the need for more systematic change to underlying markets as a key component to reducing irregular migration, and have characterised some employers as 'bad actors' and suggested that 'markets-not criminal masterminds, syndicates or networks-drive illegality' (Papademetriou, 2014, p. 2). In the context of the somewhat limited data on stocks and flows of irregular migrants, as described above, it could be hypothesised that structural labour market issues are more of an issue for some markets that have a greater reliance on irregular migration (e.g. the US and parts of Europe) compared to other markets (e.g. Australia).

\section{International obligations and state sovereignty}

The tensions between state action and international legal obligations and responsibilities are a recurring theme throughout the literature. While detailed legal and technical analysis is beyond the scope of this chapter, there are some aspects worth highlighting that demonstrate that the problems are complex and not easily reconciled.

Irregular maritime migration, in many respects, encapsulates one of the most contentious fault lines between state sovereignty and international legal obligations and responsibilities. Strong links tend to be made by 
governments between migration control, border protection and state sovereignty. Governments are often very concerned to demonstrate that they have a firm grip on the movement of people across borders-a (legitimate) sovereign right that tends to be jealously guarded (Brouwer \& Kumin, 2003; van Selm \& Cooper, 2005). 'Control over migration is interpreted ... as being somehow intrinsic to what is it to be a nation, to "stateness" and to the core of membership and national identity' (Dauvergne, 2003, p. 2).

Irregular maritime migration invokes a range of international norms and conventions in relation to human rights, law of the sea, including rescue at sea, and criminality associated with migrant smuggling and traffickingall of which makes for a complex mix (de Bruycker, di Bartolomeo, \& Fargues, 2013; Miltner, 2006). Given its visibility, and the attention irregular migration by sea attracts, the imperative to demonstrate state control of maritime borders is particularly sensitive. However, reconciling state practices to stem the flow of irregular maritime migration with international legal responsibilities and obligations is complicated by conflicting interests, blurred lines of responsibility and overlapping issues (Mallia, 2003). For example, in Europe, confusion and disagreements over territorial boundaries at sea and state responsibility for search and rescue are proving difficult to resolve. There are concerns that the confusion over who has responsibility among states undermines international cooperation to protect life at sea, seen by many as a fundamental humanitarian consideration (Annan, 2014; Mallia, 2003).

State measures to control irregular maritime migration can, and do, often clash with humanitarian considerations inherent in multiple international legal instruments that are activated in relation to irregular maritime migration, including in relation to nonrefoulement. Reconciling these conflicting interests is a fundamental challenge for all stakeholders involved. Critics of restrictive measures that are increasingly focused on preventing migrant flows from reaching their destination or from departing source and transit countries suggest that this fails to address the protection concerns of refugees caught up in irregular maritime migration flows (Dauvergne, 2003; Gammeltoft-Hansen, 2008).

Gammeltoft-Hansen (2008) suggested that this extraterritorial shift to focus on measures that attempt to deflect or prevent movement is regarded by some commentators as a geographical relocation of the border, with the potential to relocate the limits of sovereignty in relation to border 
control. Striking a balance between state sovereignty and international legal frameworks in the context of the increasing trend towards extraterritorialism in relation to irregular maritime migration, and the complex set of issues involved, is thought to be a key global challenge of the future.

Irregular maritime migration presents an undeniably visual manifestation of irregular migration and as such triggers some fundamental political and policy concerns relating to states' international protection obligations, sovereignty, border control and security, and as such demands the attention of governments (Koser \& McAuliffe, 2013; Koser, 2010; Watson, 2009). The potential and actual impacts on bilateral relationships as well as regional and broader international relationships and reputations are also key considerations for governments, including as they relate to sovereignty issues.

There is a strong sense that, notwithstanding different interests, values and priorities, as Newland pointed out, 'international migration has surpassed the ability of any one country to manage unilaterally' (Newland, 2010, p. 336). The transnational nature of irregular maritime migration demands government-to-government cooperation, including in a multilayered or tiered fashion. Engagement via multilateral forums as well as regional consultative processes are important means of understanding and working through points of convergence and divergence; these forms of engagement can also act to support or enhance bilateral cooperation.

\section{Migrants' motivations}

A number of complex, interrelated factors impact on the movement of irregular asylum and non-asylum migration flows, and in relation to why people migrate (Castles, 2013; de Haas, 2011; Havinga \& Böcker, 1999; Koser, 2011; Middleton 2005; Neumayer, 2004). Historically, academic and nonacademic writing has been dominated by the 'push-pull' model, with its roots in Ravenstein's laws of migration from the 1880s.

Today, among policymakers, the 'push-pull' theory continues to dominate, possibly because of the attractiveness it offers as a conceptually linear model. The model also downplays migrant agency, with migrants being 'pushed' and 'pulled' from and to locations. Perhaps a century ago it was highly relevant in social, economic, technological and geopolitical terms, and it offered a way of explaining and understanding migration. It is less 
relevant today, including because of the substantial social, economic, technological and geopolitical changes that have ensued in most parts of the world and that are enabling much greater transnational interaction.

Hein de Haas has argued that 'people will only migrate if they perceive better opportunities elsewhere and have the capabilities to move' (de Haas, 2011, p. 14). Through a range of dynamics (or 'enabling' factors), including diaspora and other migrant networks, de Haas argued that migrants' agency and counterstrategies can effectively undermine states' attempts to control migration. It is important to note that de Haas' theoretical discussion was not specific to irregular migration; however, he argued that refugee and asylum flows also involve agency and that "the "voluntary"-"forced" migration dichotomy is simplistic because it assumes that one category of migrants enjoys total freedom and the other category has no choice or agency at all' (de Haas, 2011, p. 14).

Adhikari's research on the relative impact of a range of factors on migrants' decision-making in Nepal highlights that migrant agency, even in extreme conflict situations, is present, and that decisions on movement were based on more than just the threat to one's life and included factors related to economic livelihoods and social networks (Adhikari, 2013). He highlighted the need for further research into the survival strategies people adopt once they decide to stay in war zones.

Much of the irregular maritime migration flows, including to Europe, Yemen, Australia and the US, are not sudden onset (although there are exceptions from time to time, such as the 2011 Libya crisis), and do involve migrant agency, and possibly considered, long-term decisionmaking processes. The number of factors impacting on movement and decision-making highlights the complex nature of irregular maritime migration. It is also important to acknowledge that none of the factors are likely to be static, and some of them can change decisively and rapidly, undoubtedly adding to the complexity of irregular migration.

The 'mixed' composition of irregular migrant populations, as opposed to past assumptions that irregular migration flows were composed primarily of asylum seekers, is a significant and important characteristic of modern manifestations of irregular migration (Miltner, 2006; Papastavridis, 2007). One of the more significant conundrums highlighted by irregular maritime migration is the 'migration-asylum nexus'. In the midst of the irregular migration flows of migrant workers are people who have moved because of war, ethnic or political persecution and meet the criteria as 
refugees. To add to the complexity, the boundaries between each group can be blurred or even change over time with migrant workers becoming refugees or vice versa (Koser, 2013).

On the one hand, the humanitarian crisis in Syria provides a very stark illustration of the fundamental need for the protection of people in fear for their lives, and of the ongoing and perhaps growing need for an effective international system that provides refugee protection. There is a clear imperative for states and international organisations to respond quickly and decisively in such situations.

When examining irregular maritime movement involving asylum seekers, onwards movement is an important consideration, as are the reasons underpinning movement. It is, in this context, useful to acknowledge Johansson's distinction between anticipatory refugee movement and acute or spontaneous movements (Johansson, 1990). As highlighted by Koser and McAuliffe, '[for] IMAs in Australia, who have undertaken long and relatively expensive journeys from their origin countries, and transited other countries where they might have remained in an irregular situation ... the choice of Australia for most ... appears to be deliberate' (2013, p. 13). Much of the movement to Australia in recent years has been anticipatory rather than acute. This, in turn, and given the substantial distances travelled from source through (multiple) transit countries to Australia, means that both the decision to leave and the choice of destination are highly relevant topics of research in the Australian context.

A further line of enquiry relevant to the examination of global irregular maritime migration is the extent to which communities actively use migration as a strategy for survival and/or to improve individual and collective outcomes. This conceptualisation of migration as a social strategy acknowledges that there are often many reasons underpinning migration that are not static but dynamic in nature, depending on prevailing circumstances. Monsutti, for example, has argued that in relation to Hazaras, no hard and fast distinction can be made between refugees and economic migrants, and that a 'migration continuum' exists that has developed as part of a broader strategy of survival (2005, pp. 168-69):

Afghans give different and usually plural reasons for their decision to migrate: perhaps an outbreak of fighting, a threat from a personal enemy, the danger of bombing or compulsory conscription; perhaps the search for work or opportunities to trade, the need for medical treatment, or the undertaking of a pilgrimage. 
When viewed as a social strategy, the existence of migration pathways and networks, including to and within destination countries, is almost certainly likely to have an impact on the tendency and ability of groups of people to migrate successfully. Migration as part of historical and cultural norms is an aspect that is prevalent in some academic discussion (Monsutti, 2005).

Some evidence of the many reasons underpinning asylum flows and the search for a better life are evident in empirical research conducted under the Irregular Migration Research Program (as described in the Preface and Introduction), and as discussed in Chapter 3 (Sri Lankan survey results) and Chapter 11 (survey of IMAs granted protection).

\section{Conclusions}

Irregular maritime migration is intrinsically linked to a range of other phenomena-regular migration, other forms of irregular migration, human development, improvements in telecommunications and the securitisation of migration. The complex, multifaceted nature of irregular maritime migration renders it a particularly challenging issue for many states around the world. The geopolitical implications now and into the future are potentially profound as origin, transit and destination states work to better manage movements and seek to avoid deaths at sea and reduce migrant vulnerability.

When examined as a global phenomenon, it is evident that South-North irregular maritime migration flows are highly visible and well documented, especially compared to other (larger) flows, including in South East Asia, Africa and the Middle East. A better understanding of the scale and nature of flows in other parts of the world, including in relation to the issues that migrants face, may raise additional challenges with broader implications for global migration movements.

There is a sense that the willingness of states to engage in forms of cooperation and collaboration on irregular maritime migration that do not involve the formulation of restrictive responses has diminished over time (Castles, 2004; de Haas, 2011). This diminution is reflective of current global and geopolitical dynamics, and in particular a growing sense of the potential for significantly increased 'unmanaged' migration in light of increased international movement (GCIM, 2005). The collaboration involved in managing earlier displacement-the Comprehensive Plan 
of Action in South East Asia to deal with flows from Vietnam and Laos being one example-appears, in a general sense, to have increasingly given way to state-centric hardening of positions.

Where there are 'pockets' or discrete groups that are able to be managed, it would appear that there is a greater degree of willingness to engage collaboratively in a positive sense in attempts to manage displacement. One such example of this can be seen in relation to states' handling of stateless groups, where the size of the stateless groups appears to be a factor (among others) in states' willingness to collaborate to find solutions with the assistance of the UNHCR. A second factor related to cooperation would appear to be related to whether the displacement issue is entrenched and/ or enduring, or more akin to an acute, sudden-onset displacement. This is perhaps best highlighted by large-scale displacement in Libya and Syria, which resulted in significant humanitarian support being provided from a range of actors, particularly at the outset. It remains to be seen how this will eventually unfold in Europe if the recent significant increases from Syria, Afghanistan, Iraq and elsewhere continue into the coming years.

In global and international discussions, it would appear that the appetite for a greater degree of convergence of approaches to restrictive migration policies, recognising migrant rights and increasing human development may well be increasing, notwithstanding the inherent difficulties in navigating a path that is able to achieve aspects of all three objectives. This will continue to be a challenge for individual nation states and regions as the global discourse evolves and expectations change. It may well be that in the future not only will migrants' aspirations increase, but significant populations may find that their capability to migrate may also increase. For some of these people, irregular maritime migration may well prove the only viable migration option.

Notwithstanding considerable challenges, it is worth reflecting on the policy and operational response capacities of some nation states to effectively harness resources (including financial, human, intellectual, technological and social, etc.) to deal with complex and difficult issues. There would appear to be a strong appetite for agile responses based on a good understanding of evidence, options, implications and risk, including in global and regional forums. One of the challenges for policymakers is to be able to deliver on all of these aspects in dynamic environments, and in an era of greater contestability. 


\section{Reference list}

Adhikari, P. (2013). Conflict-induced displacement, understanding the causes of flight. American Journal of Political Science, 57(1), 82-89. doi.org/10.1111/j.1540-5907.2012.00598.x

Australian National Audit Office. (2013). Individual management services provided to people in immigration detention. Canberra: ANAO.

Banerjee, B. (1983). Social networks in the migration process: Empirical evidence on chain migration in India. The Journal of Developing Areas, 17(2), 185-96.

Blaschke, J. (1998, 29 June - 3 July). Addressing the employment of migrants in an irregular situation: the case of Germany. Paper presented at the technical symposium on international migration and development, The Hague.

Brouwer, A., \& Kumin. J. (2003). Interception and asylum: Where migration control and human rights collide. Interception and Asylum, $21(4), 6-24$.

Campbell, A. (2014). Public interest immunity claim, January 31, 2014, Legal and Constitutional Affairs References Committee. HansardParliament of Australia.

Carling, J. (2002). Migration in the age of involuntary immobility. Journal of Ethnic and Migration Studies, 28(1), 5-42. doi.org/ $10.1080 / 13691830120103912$

Castles, S. (2002). Environmental change and forced migration: making sense of the debate. New issues in refugee research, working paper no. 70. Geneva: United Nations High Commissioner for Refugees.

Castles, S. (2004). Why migration policies fail. Ethnic and Racial Studies, 27(2), 205-227. doi.org/10.1080/0141987042000177306

Castles, S. (2013). The forces driving global migration. Journal of Intercultural Studies, 34(2), 122-40. doi.org/10.1080/07256868.201 3.781916 
Ceyhan, A., \& Tsoukala, A. (2002). The securitization of migration in western societies: Ambivalent discourses and policies. Alternatives, 27(Special Issue), 21-39. doi.org/10.1177/03043754020270s103

Clandestino Project. (2009a). Database on irregular migration, stocks of irregular migrants: Estimates for Spain. Retrieved from irregularmigration.net/typo3_upload/groups/31/3.Database_on_IrregMig/ 3.2.Stock_Tables/Spain_Estimates_IrregularMigration_Nov09_2.pdf.

Clandestino Project. (2009b). Policy brief: Size and development of irregular migration to the EU. Retrieved from irregular-migration. net/fileadmin/irregular-migration/dateien/4.Background_ Information/4.2.Policy_Briefs_EN/ComparativePolicyBrief_SizeOf IrregularMigration_Clandestino_Nov09_2.pdf.

Clarke, J. (2000). The problems of evaluating numbers of illegal migrants in the European Union. In P. de Bruycker (Ed.), Regularisations of illegal immigrants in the European Union. Brussels: Bruylant.

Conversi, D. (2012). Irresponsible radicalisation: Diasporas, globalisation and long-distance nationalism in the digital age. Journal of Ethnic and Migration Studies, 38(9), 1357-79. doi.org/10.1080/1369183X. 2012.698204

Council of Europe. (2007). The Human Rights of Irregular Migrants in Europe. Commissaire aux droits de l'homme issue paper 1. Brussels: Council of Europe. Retrieved from rm.coe.int/16806da797.

Crisp, J. (1999). Policy challenges of the new diasporas: migrant networks and their impact on asylum flows and regimes. ESRC transnational communities programme working paper. Oxford, University of Oxford.

Dauvergne C. (2003, April). Challenges to sovereignty: Migration laws for the 21st century. Paper presented at the 13th Commonwealth law conference, Melbourne.

de Bruycker, P., di Bartolomeo, A., \& Fargues, P. (2013). Migrants smuggled by sea to the EU: Facts, laws and policy options. Migration Policy Centre research report. Florence: European University Institute. 
de Haas, H. (2005). Morocco: From Emigration Country to Africa's Migration Passage to Europe. Washington DC: Migration Policy Institute. Retrieved from www.migrationpolicy.org/article/moroccoemigration-country-africas-migration-passage-europe.

de Haas, H. (2011). The determinants of International migration: conceptualising policy, origin \& destination effects. Working paper. Oxford: International Migration Institute. Retrieved from www.imi. ox.ac.uk/publications/wp-32-11.

Department of Immigration and Border Protection. (2010). Fact sheet 86-Overstayers and other unlawful non-citizens. Canberra: Author.

Department of Immigration and Citizenship. (2012-13). Annual report. Canberra: Commonwealth of Australia.

Doneys, P. (2011). En-gendering insecurities: The case of the migration policy regime in Thailand. International Journal of Social Quality, 1(2), 50-65. doi.org/10.3167/IJSQ.2011.010205

European Migration Network. (2012). Practical measures to reduce irregular migration, European Migration Network synthesis report. Retrieved from ec.europa.eu/home-affairs/sites/homeaffairs/files/what-we-do/ networks/european_migration_network/reports/docs/emn-studies/ irregular-migration/00a_emn_synthesis_report_irregular_migration_ october_2012_en.pdf.

Faist, T. (2004). The migration-security nexus: International migration and security before and after 9/11. Willy Brandt series of working papers in international migration and ethnic relations. Sweden: Malmo University.

Frontex (European Agency for the Management of Operational Coordination at the External Borders of the Member States of the European Union). (2010). Frontex annual risk analysis 2010. Warsaw, Poland: Frontex.

Frontex (European Agency for the Management of Operational Coordination at the External Borders of the Member States of the European Union). (2013). Frontex annual risk analysis 2013. Warsaw, Poland: Frontex. 
Frontex (European Agency for the Management of Operational Coordination at the External Borders of the Member States of the European Union). (2015). Frontex annual risk analysis 2014, Warsaw, Poland: Frontex.

Gammeltoft-Hansen, T. (2008). The refugee, the sovereign and the sea: EU interdiction policies in the Mediterranean. Danish Institute for International Studies (DIIS) working paper 6, Copenhagen.

Global Commission on International Migration. (2005). Migration in an interconnected world: New directions for action. Geneva: Author.

Gomez, O.A., \& Gasper, D. (2013) Human security: A thematic Guidance note for regional and national human development report teams. New York: United Nations Development Programme.

Gordon, I., Scanlon, K., Travers, T., \& Whitehead, C. (2009). Economic Impact on London and the UK of an Earned Regularisation of Irregular Migrants in the UK. London: Greater London Authority.

Havinga, T., \& Böcker, A. (1999). Country of asylum by choice or by chance: asylum-seekers in Belgium, the Netherland and the UK. Journal of Ethnic and Migration Studies, 25(1), 43-61. doi.org/10.108 0/1369183X.1999.9976671

Hoefer, M., Rytina, N., \& Baker, B. (2011). Estimates of the unauthorized immigrant population residing in the United States. Office of Immigration Statistics, US Department of Homeland Security. Retrieved from www.dhs.gov/sites/default/files/publications/Unauthorized $\% 20$ Immigrant $\% 20$ Population $\% 20$ Estimates $\% 20$ in $\% 20$ the $\% 20$ US $\% 20$ January\%202011_0.pdf.

Hollifield, J. (2004). The emerging migration state. The International Migration Review, 38(3), 885-912. doi.org/10.1111/j.1747-7379. 2004.tb00223.x

Hopkins, L. (2009). Media and migration: a review of the field. Australian Journal of Communication, 36(2), 35-54.

Hugo, G. (2014) The changing dynamics of ASEAN international migration. Malaysian Journal of Economic Studies 51(1): 43-67. 
Humphrey, M. (2013). Migration, security and insecurity. Journal of Intercultural Studies, 34(2), 178-95. doi.org/10.1080/07256868.201 3.781982

Huysmans, J. (2000). The European Union and the securitization of migration. Journal of Common Market Studies, 38(5), 751-77. doi.org/ $10.1111 / 1468-5965.00263$

International Migration Institute. (2006). Towards a new agenda for international migration research. Oxford: Author. Retrieved from www. imi.ox.ac.uk/publications/towards-a-new-agenda-for-internationalmigration-research.

International Organization for Migration. (2010). Labour migration from Indonesia. Jakarta: Author.

Johansson, R. (1990). The refugee experience in Europe after World War II: Some theoretical and empirical considerations. In Rystad, G. (Ed.), The uprooted: Forced migration as international problem in the post war era (pp. 227-62). Lund: Lund University Press.

Kim, S., Carvalho, J., Davis, A., \& Mullins, A. (2011). The view of the border: News framing of the definition, causes, and solutions to illegal immigration. Mass Communication and Society, 14, 292-314. doi.org/ $10.1080 / 15205431003743679$

Koser, K. (2005, September). Irregular migration, state security and human security. Paper prepared for the policy analysis and research programme of the Global Commission on International Migration. Geneva: GCIM. Retrieved from www.peacepalacelibrary.nl/ebooks/files/GCIM_TP5.pdf.

Koser, K. (2010). Dimensions and dynamics of irregular migration. Population, Space and Place, 16(3), 181-93. doi.org/10.1002/psp.587

Koser, K. (2011). The smuggling of refugees. In D. Kyle, \& R. Koslowski (Eds), Global human smuggling (pp. 257-72). Baltimore, MD: Johns Hopkins University Press.

Koser, K., \& McAuliffe, M. (2013). Establishing an evidence-base for future policy development on irregular migration to Australia. Irregular Migration Research Program, Occasional Paper Series 01. Canberra: 
Australian Department of Immigration and Citizenship. Retrieved from www.border.gov.au/ReportsandPublications/Documents/research/ evidence-base-for-future-policy.pdf.

Koser, K., \& Pinkerton, C. (2002). The social networks of asylum seekers and the dissemination of information about countries of asylum. London: UK Home Office.

Mallia, P. (2003). The challenges of irregular migration. Jean Monnet occasional papers no. 4. Malta: Institute for European Studies.

Martin, P., \& Taylor, J. (1996). The anatomy of a migration hump. In Taylor, J. (Ed.), Development strategy, employment, and migration: Insights from models (pp. 43-62). Paris: OECD Development Centre.

Meyer, J. B. (2001). Network approach versus brain drain: Lessons from the diaspora. International Migration, 39. Oxford: Blackwell Publishers Ltd.

Middleton, D. (2005). Why asylum seekersseek refuge in particular destination countries: an exploration of key determinants. Global Migration Perspectives, No. 34. Geneva: Global Commission on International Migration. Retrieved from www.refworld.org/docid/42ce54774.html.

Miggiano, L. (2009, November). States of exception: securitisation and irregular migration in the Mediterranean. New issues in refugee research, no. 177. Geneva: United Nations High Commissioner for Refugees. Retrieved from www.refworld.org/docid/4c232575a.html.

Miltner, B. (2006). Irregular maritime migration: Refugee protection issues in rescue and interception. Fordham International Law Journal, 30(1), 75-125.

Monsutti, A. (2005). War and migration: Social networks and economic strategies of the Hazaras of Afghanistan. London: Routledge.

Morrison, S. (2014). Public interest immunity claim, January 31, 2014, Legal and Constitutional Affairs References Committee. HansardParliament of Australia.

Mulvey, G. (2010). When policy creates politics: The problematizing of immigration and the consequences for refugee integration in the UK. Journal of Refugee Studies, 23, 437-62. doi.org/10.1093/jrs/feq045 
Nedelcu, M. (2012). Migrants' new transnational habitus: Rethinking migration through a cosmopolitan lens in the digital age. Journal of Ethnic and Migration Studies, 38(9), 1339-56. doi.org/10.1080/1369 183X.2012.698203

Neumayer, E. (2004). Asylum destination choice-What makes some West European countries more attractive than others? European Union Politics, 5(2), 155-80. doi.org/10.1177/1465116504042444

Newland, K. (2010). The governance of international migration: Mechanisms, processes and institutions. Global Governance, 16, 331-43.

Panagakos, A., \& Horst, H. (2006). Return to Cyberia: Technology and the social worlds of transnational migrants. Global Networks, 6(2), 109-24.

Papademetriou, D. (2014). Curbing the influence of 'bad actors' in international migration. Washington DC: Migration Policy Institute. Retrieved from www.migrationpolicy.org/research/curbing-influencebad-actors-international-migration.

Papastavridis, E. (2007, 28-29 September). Interception of human beings on the high seas under the law of the sea convention. Paper presented at the second European Society of International Law (ESIL) research forum, Budapest.

Passel, J., Cohn, D., \& Gonzalez-Barrera, A. (2013). Population decline of unauthorized immigrants stalls, may have reversed. Washington DC: Pew Research Centre. Retrieved from www.pewhispanic.org/2013/09/23/ population-decline-of-unauthorized-immigrants-stalls-may-havereversed/.

Pastore, F., Monzini, P., \& Sciortino, G. (2006). Schengen's soft underbelly? Irregular migration and human smuggling across land and sea borders to Italy. International Migration, 44(4), 95-119. doi.org/ 10.1111/j.1468-2435.2006.00381.x

Phillips, J., \& Spinks, H. (2013). Boat arrivals in Australia since 1976. Parliamentary library research paper. Canberra: Parliament of Australia. Retrieved from www.aph.gov.au/About_Parliament/Parliamentary_ Departments/Parliamentary_Library/pubs/rp/rp1314/BoatArrivals. 
Pickering, S. (2001). Common sense and original deviancy: News discourse and asylum seekers in Australia. Journal of Refugee Studies, 14(2), 169-86. doi.org/10.1093/jrs/14.2.169

Rabogoshvili, A. (2012). Chinese migration to Russia as revealed by narratives in Chinese cyberspace. Journal of Current Chinese Affairs, 41(2), 9-36.

Regional Mixed Migration Secretariat. (2013). Responses to mixed migration in the Horn of Africa and Yemen: Policies and assistance responses in a fast-changing context. Nairobi: Author.

Rosenblum, M. (2012). Border security: Immigration enforcement between ports of entry. Washington DC: Congressional Research Service.

Simanski, J., \& Sapp, L. (2012). Immigration enforcement actions: 2012. US Department of Homeland Security, Annual Report. Retrieved from www.dhs.gov/sites/default/files/publications/Enforcement_Actions _2012.pdf.

Skeldon, R. (1997). Migration and development: A global perspective. Essex: Longman.

Staring, R. (2004). Facilitating the arrival of illegal immigrants in the Netherlands: Irregular chain migration versus smuggling chains. Journal of International Migration and Integration, 5(3), 273-94. doi.org/10.1007/s12134-004-1015-9

Terrazas, A. (2011). Migration and development: Policy perspectives from the United States. Washington DC: Migration Policy Institute.

Threadgold, T. (2009). The media and migration in the United Kingdom, 1999 to 2009. Washington DC: Migration Policy Institute.

United Nations Department of Economic and Social Affairs. (2003). Trends in total migrant stock: The 2003 revision. New York: Author.

United Nations Department of Economic and Social Affairs. (2016). Trends in international migrant stock: The 2015 revision. New York: Author. Retrieved from www.un.org/en/development/ desa/population/migration/data/estimates $2 /$ index.shtml.

United Nations High Commissioner for Refugees. (2015). UNHCR Population Statistics database. Retrieved from popstats.unhcr.org/. 
United Nations Office on Drugs and Crime. (2011). Smuggling of migrants: A global review and annotated bibliography of recent publications. New York: United Nations. Retrieved from www.unodc.org/documents/ human-trafficking/Migrant-Smuggling/Smuggling_of_Migrants_A_ Global_Review.pdf.

United States Coast Guard. (2014). Maritime Migrant Interdictions: 1982 - Present. Washington DC: Author.

United States Customs and Border Protection. (2014). CBP releases fiscal year 2013 statistics. Access 3(2), 1. Retrieved from www.cbp.gov/sites/ default/files/assets/documents/2017-Mar/cbpaccessv3.02-012414.pdf.

van Selm, J., \& Cooper, B. (Eds). (2005). The new 'boat people': Ensuring safety and determining status. Washington DC: Migration Policy Institute. Retrieved from www.migrationpolicy.org/research/newboat-people-ensuring-safety-and-determining-status.

Vertovec, S. (2009). Transnationalism. London and New York: Routledge.

Watson, S. (2009). The securitisation of human migration: Digging moats and sinking boats. London: Routledge.

Weaver, O. (1995). Securitization and desecuritization. In Lipschultz, R. (Ed.), On security. New York: Columbia University Press.

World Bank. (2015). World Bank world development indicators. Retrieved October 21, 2015 from data.worldbank.org.

Zelinsky, Z. (1971). The hypothesis of the mobility transition. Geographical Review 61(2), 219-49. doi.org/10.2307/213996

\section{Media}

Annan, K. (2014, 2 January). Sympathy for the migrant. Project Syndicate. Retrieved from www.project-syndicate.org/commentary/kofi-a-annancalls-for-a-new-understanding-of-migration-as-an-essential-part-of-thehuman-experience.

Koser, K. (2011, 31 March). When is migration a security issue? Brookings blog. Retrieved from www.brookings.edu/research/ opinions/2011/03/31-libya-migration-koser. 
Koser, K. (2012, 15 August). Securitizing migration: A good or bad idea? (International Relations and Security Network, Zurich, Interviewers) [audio recording]. Retrieved from www.video.ethz.ch/campus/isn/ e64b372e-c59e-4fbb-a091-6bfe68d9a17f.html.

Koser, K. (2013). Australia missing the lessons of Lampedusa. The Interpreter. Retrieved from www.lowyinstitute.org/the-interpreter/ australia-missing-lessons-lampedusa.

Walker, I. (2013, 13 August). Saudi Arabia and its immigrants. The Centre of Migration Policy \& Society blog. Retrieved from www.compas. ox.ac.uk/2013/saudi-arabia-and-its-immigrants/. 
This text is taken from A Long Way to Go: Irregular Migration Patterns, Processes, Drivers and Decision-making, edited by Marie McAuliffe and Khalid Koser, published 2017 by ANU Press, The Australian National University, Canberra, Australia.

dx.doi.org/10.22459/LWG.12.2017.02 